\title{
Environmental Water Price Based on Water Environment Capacity and Ecological Water Consumption: A Case Study of Hefei
}

\author{
Yuzhen Duan', Guijian Liu',2, Chong Ren'1, Xiaobao Peng ${ }^{1}$ \\ ${ }^{1}$ School of Public Affairs, University of Science \& Technology of China, Hefei, China \\ ${ }^{2}$ School of Earth and Space Sciences, University of Science and Technology of China, Hefei, China \\ Email:dyzp88@gmail.com
}

Received 12 January 2016; accepted 25 April 2016; published 28 April 2016

Copyright (C) 2016 by authors and Scientific Research Publishing Inc.

This work is licensed under the Creative Commons Attribution International License (CC BY). http://creativecommons.org/licenses/by/4.0/

c) (†) Open Access

\begin{abstract}
With the development and reform of water price policy, the most common view is that the total cost of water price can reflect the tradable traits of water resources, which can enhance the water use efficiency and achieve water resources sustainable utilization. Besides in actual pricing operation, from the angle of protection cost, water price characterizes the cost of controlling pollution and protecting water environment. Based on the two factors of water environment capacity and ecological water consumption embodied by the environment water price, this paper puts forward an effective environmental water price calculation model based on three elements of sewage treatment fee, ecological water price and water quality maintenance fee. And this paper takes the data of Hefei as an example, calculates reasonable environmental price, comparing which with the existing price, and finds the main existing problem which needs to be solved urgently in management.
\end{abstract}

\section{Keywords}

Environmental Water Price, Sewage Treatment Fee, Ecological Water Price, Water Quality Maintenance Fee

\section{Introduction}

Because of the scarcity of water resources, and scale economy effect of water supply and wastewater treatment, water industry has been naturally monopolized, which needs to be formed and maintained through government regulation, and also needs price regulation and other regulatory to prevent bad economic consequences arising 
from the free decision of the enterprise under the monopoly [1].

At present and in the future, the basic goal of the reform of water price in China is to establish the water price mechanism, which can reflect the shortage of water resources, improve water efficiency, promote sustainable utilization of water resources [2]-[4]. Besides the water price shall gradually reflect total cost of water, promote the water company achieve real business operation, and promote the whole society to save water, use water efficiently [5].

In the evolution and reform of water price policy, the total cost is generally considered to be able to reflect the tradable traits of water resources and achieve sustainable use of water resources. In the reform of water price theory and water price policy, our country gradually establish a "triple water price system" based on total cost, including the resource water price, engineering water price and environmental water price, in which all cost arising from the cyclic process of the water resources has been included [6] [7].

In theory, our country charges for water intake in the form of "fee" based on the state ownership of water resources, and the main purpose is to protect the water resources, and to prevent water environmental damage. In triple water price system, the environmental water price is a kind of environmental damage cost [8], which means the used water drained away pollute others' or public water environment [9]. In another word, the payment is for the right to use a certain environmental capacity [10]. In actual pricing operation, from the angle of "protection cost" water price characterizes the cost of controlling pollution and protecting water environment, and specifically reflected in the sewage treatment fee [11].

From an economic perspective water prices should reflect the real water resources value. This leads to a question how to evaluate the real water resources value? The environmental water price is an approach to quantify the real part value of water resources, also reflecting its scarcity [12]. Some researchers have been conducted to estimate the environmental water price of different kinds of water resources [13]-[15]. Nevertheless, it was also said that, in practice, it is almost impossible to obtain environmental water price by solving a linear programming problem [16]. This paper tries to answer this demand combining water environmental capacity-ecological water consumption analysis method with linear programming model to evaluate environmental water price in Hefei.

\section{The Factors of Environmental Water Price}

\subsection{Water Environmental Capacity}

Water environmental capacity refers to the maximum amount of pollutants in the development and utilization area of water resources, based on the given water quality objective and designed water quantity and water quality condition [17]. Water environmental capacity is composed of two parts, dilution capacity and self purification capacity, reflect the physical dilution and natural purification of pollutants migrated in the water respectively. As long as there is a dilution of water, there is a dilution capacity. As long as there is a comprehensive attenuation factor, there is self purification capacity. Calculate the capacity of water pollution, multiply "water pollution capacity" by the "safety factor", and then confirm the control objectives of the total amount of pollutant emissions through technical and economic feasibility studies, that is the regional allowable emissions [18].

To carry out water environment capacity, we need to follow the following steps: In the first place, we must confirm water function area and determine water quality objectives of the functional area according to the natural and social environment, social and economic development and water resources distribution law and other factors [19]. Secondly, confirm hydrologic design condition according to the hydrological and water resources characteristics of the functional area. Then analyze the way to enter the functional area of pollutant, especially the position of the discharge port, the amount of pollutant, types, concentration and the law of discharge of pollutant. Finally, choose water quality model to analyze and calculate [20].

This calculation can generally be divided into two types: forward calculation and inverse calculation. Forward calculation mainly calculates distribution law of water pollutant concentration based on the hydrological conditions and pollution source condition in area [21]. And then compare it with water quality objectives, to analyze and evaluate water quality condition. Reverse calculation mainly calculate the allowable discharge amount of pollutants with water quality model according to the water quality objectives of the functional area, that is the pollutant concentration in the water area [22] [23]. With the results, we can analyze and determine the water pollution capacity.

Water pollution capacity is established by water quality objectives and the diffusion, assimilation, self purifi- 
cation law of water [24]. The basic equation can be expressed as:

$$
W=\left(C_{n}-C_{o}\right) Q+K \frac{X}{U} C_{n} Q
$$

In which:

1) W: Water pollution capacity, which can be expressed by the total amount of pollutants, or pollutant concentration multiply water consumption;

2) $C_{n}$ : Water quality standards;

3) $Q$ : water consumption

4) $C_{0}$ : The natural background values of pollutants in the water, or the concentration of pollutants in the water;

5) $X$ : The distance;

6) $U$ : The average velocity of water;

7) $K$ : The attenuation coefficient of the pollutant.

\subsection{Ecological Water Consumption}

The ecological environment is the basic natural condition for the development of human existence, and the water plays a critical role in the maintenance of the ecological environment. For a long time, in the development and utilization of water resources human beings only pay attention to the needs of production and living water, while lack awareness of the mutual dependency relation between the protection of water resources and the ecological environment, and ignore the ecological water, resulting a series of ecological environment problems. Over exploitation of water resources cause the atrophy of rivers, lakes and wetlands, river blanking, wildlife habitat destruction, loss of biodiversity, river siltation, reduced self purification capacity of water [25]. And the deterioration of water environment has been an increasingly serious ecological and environmental problems.

Ecological water is also known as water for environment, eco-environmental water or eco-environmental water demand. The generalized eco-environmental water means the water needed to maintenance the water balance in the global biological and ecological systems, including water needed in water and heat balance, biological balance, water-sediment balance, water-salt balance; Eco-environmental water in the narrow sense refers to the water resources quantity needed to stop the degradation of the ecological environment [26], and gradually improve the amount of water consumption. Ecological water is a part of water resources, which is necessary to maintain the integrity of the ecosystem [27]. It's also a part of water consumption.

According to the ecological environment function of the ecosystem, the ecological environment water consumption can be divided into: river eco-environment water demand, vegetation eco-environment water demand, the ecological water used to protect wetland, urban ecological water demand and the ecological water demand for filling back over exploitation of groundwater [28].

River eco-environment water demand is divided into: water used in conservation of water and soil, river ecological water consumption, river water evaporation, river water leakage, water volume required for transporting sediment, water consumption into the sea, and river landscape and water recreation environment water demand etc. [29]. In which the river ecological water consumption is the main component. The western United States has played more attention to increase the water flow to improve the water quality and the living environment of wild animals and plants, such as fish. Federal agencies, state government agencies, and the private sector obtain the river discharge through different ways like lease, purchase and donation. The ways of calculating river ecoenvironment water demand are hydrology, hydraulics and habitat method, and the Tennant method in hydrology, namely: take percentage of natural runoff volume as the habitat of river water demand, and take the $10 \%$ of mean annual flow as the minimum of river ecological water demand [30] [31].

Lake ecological water consumption includes the amount of evaporation loss, leakage loss and the amount of water needed to protect the habitat of the lake. Lake surface evaporation is one of the important ways of water consumption, which requires a certain amount of water to maintain the environmental function of the lake system. When the water surface evaporation is higher than precipitation, the net amount of water evaporation is calculated by the difference between the water surface evaporation and the precipitation, which is called water surface evaporation [32]. When the precipitation is higher than evaporation, the evaporation water consumption is considered as zero. The calculation formula is as following: 


$$
\begin{cases}W_{E}=\frac{A(E-P)}{1000} & E>P \\ W_{E}=0 & E<P\end{cases}
$$

1) $W_{E}$ represents water surface evaporation $\left(\mathrm{m}^{3}\right)$;

2) $A$ represents the area of water surface area $\left(\mathrm{m}^{2}\right)$;

3) $E$ represents average annual evaporation $(\mathrm{mm})$,

4) $P$ represents average annual precipitation $(\mathrm{mm})$. When the water level of lake is higher than the groundwater level, the groundwater is supplied by the river water, and the leakage loss is calculated according to Darcy's formula. The proportion of water demand for lake habitats in available water supply is not less than the proportion of the water demand for river habitat in annual runoff volume, in which take $10 \%$ of the available water supply amount as water demand for lake habitats.

\section{The Calculation of Environmental Water Price}

Environmental water price $\left(P_{E}\right)$ refers to the impact of water intaking on water ecology, and the used water discharged pollute others or public water environment, that is the cost of controlling pollution and protecting environment [33]. This study considers that the environmental water price is composed of three parts: 1) sewage treatment fee $\left.\left(P_{S}\right) ; 2\right)$ the compensation for the impact of water intaking on ecological water, which is reflected as ecological water price; 3 ) Waste water discharged exceeds the water environment capacity, that is the compensation for the damage to the water quality, which is reflected as maintenance fees of water quality. Therefore, the specific calculation method of environmental water price is as follows:

$$
P_{E}=P_{S}+P_{E C}+P_{Q}
$$

\subsection{Sewage Treatment Fee}

Sewage treatment fee $\left(P_{S}\right)$ can be calculated with the unit investment costs plus the unit water price of treatment and unit sludge treatment fee:

$$
P_{S}=P_{S 1}+P_{S 2}+P_{S 3}
$$

The unit investment $P_{S 1}$ cost can be calculated according to the average incremental cost of sewage treatment investment [34].

The plan has a duration of $m$ year, the investment of the sewage treatment project in the $t$ years is $I_{t}$ (unit: ten thousand RMB), and the service life of the project is $n$ years. The calculation formula is as following:

$$
P_{S}=\left[\sum_{t=1}^{m} I_{t} /(1+r)^{t}\right] /\left[\sum_{t=1}^{n} Q_{d} \times 365 /(1+r)^{t}\right]
$$

$Q_{d}$ represents the increasingly daily water consumption, $r$ represents discount rate.

The unit price of water treatment $P_{S 2}$ is fees charged by the sewage plant in daily business process, which can be handled by the method of weighted mean.

\subsection{Ecological Water Price}

The compensation for the impact of water intaking on the ecological water is reflected in the value of the ecological water consumption in the water price, which is called ecological water price.

Ecological water consumption is a part of water resources [35], and the ecological water price can be obtained by the method of modified water price [36]. The smaller of proportion of the water supply quantity $\left(Q_{A}\right)$ and the water demand $\left(Q_{R}\right)$, the greater the value of the ecological water in water price, which means ecological water price is proportional to $Q_{E C} / Q_{A}$, and inversely proportional to $Q_{A} / Q_{R}$. This study makes the following demonstrative research on the ecological water price:

$$
P_{E C}=P_{R} \times \frac{Q_{E C} / Q_{A}}{Q_{A} / Q_{R}}
$$


In which, $P_{E C}$ represents ecological water price, $P_{R}$ represents water resource price.

\subsection{Maintenance Costs of Water Quality}

Maintenance costs of water quality $\left(P_{Q}\right)$ is the compensation for the impact of sewage discharge on the water environment, which is used for the restoration of water environment. From the perspective of property right relation, this is the property damage caused by sewage discharge to the owner (state and Society). Therefore, persons who discharge wastewater should make economic compensation to the owners. Sewage charge is a form of economic compensation [37].

From the point of appropriation expenditure, when water resources are polluted, it will affect the use of water resources in various aspects of the national economy. In order to ensure the water quality of water resources, the government needs to treat water pollution. The investment of controlling water pollution and the corresponding regular cost from the government form maintenance costs of water quality.

\section{The Calculation Results of Environmental Water Price in Hefei}

\subsection{Sewage Treatment Costs}

This study calculates the unit cost of sewage treatment with the cost of investment of sewage treatment plant and unit treatment cost of Hefei in 2009. In 2009 Hefei, there are 7 various types of sewage treatment plants, including Wang Xiaoying, first phase of Wang Tang, first phase of Zhu Zhuanjing, first phase of Economic Development Zone, first phase of Cai Tianpu, Shi Wulihe, Vocational Education City, and the total processing capacity amounts to $6,150,000$ tons/day (Table 1).

Calculating unit investment cost by average incremental method:

$$
P_{S 1}=\left[\sum_{t=1}^{m} I_{t} /(1+r)^{t}\right] /\left[\sum_{t=1}^{n} Q_{d} \times 365 /(1+r)^{t}\right]
$$

In which $m=5, I_{t}=27741.88, R$ takes a five-year loan interest rate of $6.45 \%$. The project life is calculated as 20 years. The average daily treatment amount of sewage is 363,600 tons in 2005 . And the average daily treatment capacity of sewage is 667,500 tons. $Q_{d}=303900$. Annual unit investment cost in 2009 is as following:

$$
\begin{aligned}
P_{S 1} & =\left[\sum_{t=1}^{5} 27741.88 /(1+6.45 \%)^{t}\right] /\left[\sum_{t=1}^{20} 30.39 \times 365 /(1+6.45 \%)^{t}\right] \\
& =\frac{167972.51}{455965.59}=0.37 \text { yuan } / \text { ton }
\end{aligned}
$$

\begin{tabular}{|c|c|c|c|c|c|c|c|}
\hline $\begin{array}{l}\text { Name of sewage } \\
\text { treatment plant }\end{array}$ & $\begin{array}{c}\text { Amount of } \\
\text { investment (10 } \\
\text { thousand yuan) }\end{array}$ & $\begin{array}{l}\text { unit } \\
\text { treatment } \\
\text { cost }\end{array}$ & $\begin{array}{c}\text { ADTA in } \\
2005(10 \\
\text { thousand } \\
\text { tons) }\end{array}$ & $\begin{array}{c}\text { ADTA in } \\
2006(10 \\
\text { thousand } \\
\text { tons) }\end{array}$ & $\begin{array}{c}\text { ADTA in } \\
2007 \text { (10 } \\
\text { thousand } \\
\text { tons) }\end{array}$ & $\begin{array}{c}\text { ADTA in } \\
2008(10 \\
\text { thousand } \\
\text { tons) }\end{array}$ & $\begin{array}{c}\text { ADTA in } \\
2009(10 \\
\text { thousand } \\
\text { tons) }\end{array}$ \\
\hline $\begin{array}{l}\text { first phase of Zhu } \\
\text { Zhuanjing }\end{array}$ & 12,024 & 0.3624 & 2.92 & 4.34 & 4.65 & 5.42 & 5.99 \\
\hline $\begin{array}{c}\text { first phase of Wang } \\
\text { Tang }\end{array}$ & 15,200 & 0.3281 & 7.26 & 8.16 & 8.7 & 9 & 9.06 \\
\hline Wang Xiaoying & 65,000 & 0.8153 & 26.18 & 28.18 & 30.34 & 32.88 & 33.76 \\
\hline $\begin{array}{c}\text { first phase of } \\
\text { Economic } \\
\text { Development Zone }\end{array}$ & 14,000 & 0.293 & & & 3.54 & 7.13 & 11.09 \\
\hline Cai Tianpu & 9687.92 & 0.2833 & & & & 1.5 & 2.362 \\
\hline Shi Wulihe & $21,110.99$ & 0.256 & & & & & 4.24 \\
\hline $\begin{array}{c}\text { Vocational } \\
\text { Education City }\end{array}$ & 1686.5 & 0.86 & & & & & 0.2516 \\
\hline
\end{tabular}

Table 1. General situation of sewage treatment plant in Hefei.

Note: ADTA: Average daily treatment amount. 
The unit cost of sewage treatment is calculated with the method of weighted mean in 2009

$$
\begin{aligned}
P_{S 2} & =\frac{5.99 \times 0.3624+9.06 \times 0.3281+33.76 \times 0.8153+11.09 \times 0.293+2.362 \times 0.2833+4.24 \times 0.256+0.2516 \times 0.86}{5.99+9.06+33.76+11.09+2.362+4.24+0.256} \\
& =\frac{37.89}{66.75}=0.57 \text { yuan } / \text { ton }
\end{aligned}
$$

Unit cost of sludge disposal $P_{S 3}$ :

$$
P_{S 3}=\frac{2460}{66.75 \times 365}=0.10 \text { yuan } / \text { ton }
$$

The unit cost of sewage treatment of Hefei in 2009:

$$
P_{S}=P_{S 1}+P_{S 2}+P_{S 3}=0.37+0.57+0.10=1.04 \text { yuan } / \text { ton }
$$

\subsection{Ecological Water Price}

In Hefei, the amount of the average annual surface water resources from 1956 to 2000 is $1.729 \mathrm{billion} \cdot \mathrm{m}^{3}$, the amount of the average annual groundwater resources is 516 million $\cdot \mathrm{m}^{3}$. Excluding repeat $473 \mathrm{million} \cdot \mathrm{m}^{3}$, The total amount of the average annual water resources is 1.772 billion $\cdot \mathrm{m}^{3}$. Thus per capita amount of water resources is $364 \mathrm{~m}^{3}$.

At the end of 2008 the large and medium-sized reservoir storage is 280 million $\cdot \mathrm{m}^{3}$, the storage of small reservoirs and embankments is $338 \mathrm{million} \cdot \mathrm{m}^{3}$. The total storage is $618 \mathrm{million} \cdot \mathrm{m}^{3}$, existing a decrease of $66 \mathrm{mil}-$ lion $\cdot \mathrm{m}^{3}$ compared with last year. The total water supply is $1.988 \mathrm{billion} \cdot \mathrm{m}^{3}$, existing an increase of 126 million $\cdot \mathrm{m}^{3}$ over last year. The total water supply of surface water is $1.948 \mathrm{billion} \cdot \mathrm{m}^{3}$, in which the amount of water diversion by Pi Shihang project is $344 \mathrm{million} \cdot \mathrm{m}^{3}, 19$ million $\cdot \mathrm{m}^{3}$ groundwater supply, and $21 \mathrm{million} \cdot \mathrm{m}^{3}$ of other water supply.

In 2008 the city's total water consumption is $1.988 \mathrm{billion} \cdot \mathrm{m}^{3}$, existing an increase of $126 \mathrm{million} \cdot \mathrm{m}^{3} \mathrm{com}$ pared with last year. In which: 937 million $\mathrm{m}^{3}$ of agricultural irrigation water, existing an increase of 43 million $\cdot \mathrm{m}^{3}$ over the previous year, occupies $47.1 \%$ of the total amount of water; 53 million $\mathrm{m}^{3}$ of water consumption in forestry, animal husbandry and fishery, existing a decrease of 4 million $\mathrm{m}^{3}$, occupies $2.7 \%$ of the total amount of water; 702 million $\cdot \mathrm{m}^{3}$ of industrial water, existing an increase of 69 million $\cdot \mathrm{m}^{3}$, occupies $35.3 \%$ of the total amount of water; 59 million $\mathrm{m}^{3}$ of water consumption in public city, existing an increase of $3 \mathrm{million} \cdot \mathrm{m}^{3}$, occupies $3 \%$ of the total amount of water; 46 million $\mathrm{m}^{3}$ of water demand in households, existing an increase of 11 million $\cdot \mathrm{m}^{3}$, occupies $9.6 \%$ of the total amount of water; 46 million $\cdot \mathrm{m}^{3}$ of eco-environmental water, existing an increase of 4 million $\mathrm{m}^{3}$, occupies $2.3 \%$ of the total. Thus the total amount of water consumption increased this year, mainly in the industrial water consumption.

According to results above, we can draw that to maintain the current environmental state

$Q_{E C}=0.46$ million $\cdot \mathrm{m}^{3}, Q_{A}=1.772$ billion $\cdot \mathrm{m}^{3}, Q_{R}=1.988 \mathrm{billion} \cdot \mathrm{m}^{3}$, and $P_{R}=0.82$ yuan $/$ ton

$$
P_{E C}=P_{R} \times \frac{Q_{E C} / Q_{A}}{Q_{A} / Q_{R}}=0.82 \times \frac{0.46 \times 19.88}{17.72 \times 17.72}=0.02 \text { yuan } / \text { ton }
$$

\subsection{Maintenance Costs of Water Quality}

According to the date of Environmental Protection Bureau of Hefei, a total amount of 25.5157 million-yuan had been charged for sewage, thus we can calculate the unit maintenance costs of water quality:

$$
P_{Q}=\frac{2551.57}{66.75 \times 365}=0.10 \text { yuan } / \text { ton }
$$

According to the above analyses, environmental water price of Hefei can be drawn:

$$
P_{E}=P_{S}+P_{E C}+P_{Q}=1.04+0.02+0.10=1.16 \text { yuan } / \text { ton }
$$

Drawn from the above estimates, the environmental water price is $1.16 \mathrm{yuan} / \mathrm{m}^{3}$ in Hefei, which constitutes an important part of the whole cost of the water price. 


\section{Discussion and Conclusion}

\subsection{Discussion}

Since the introduction of sewage treatment fee in 1996, and three times adjustment in 2000, 2002 and 2007, according to the actual needs of sewage treatment and objective need of economic and social development, Hefei city gradually improve the collection standard of sewage treatment fee, perfect the collection mechanism, which make the collection of sewage treatment fee much more standardized, scientific and reasonable. To a certain extent, it makes up the capital gap, and ensures the normal operation of urban sewage treatment facilities and the construction, transformation and maintenance of urban sewage network [38].

According to the estimate, the environmental water price of Hefei should be $1.16 \mathrm{yuan} / \mathrm{m}^{3}$. However, in fact, in June 2007 after the adjustment, the scope of water resources, the collection standard, the collection way, the charge management, range of application are as following: water demand in households is $0.76 \mathrm{yuan} / \mathrm{m}^{3}$, industrial water (including official water) is $0.845 \mathrm{yuan} / \mathrm{m}^{3}$, water used in business service is $1.215 \mathrm{yuan} / \mathrm{m}^{3}$, special water is 1.765 yuan $/ \mathrm{m}^{3}$ (Table 2). Sewage treatment fee takes different rates to different users, which is based on different water consumption while not drainage water quality. The rate of special industry with large water consumption is highest, business service industry is second, then administrative undertaking, and water demand in households is lowest. The weighted rate is about $0.88 \mathrm{yuan} / \mathrm{m}^{3}$. It is easy to find that the charged sewage treatment fee can not meet the needs of the city's sewage treatment business, resulting in a big funding gap.

Although the collection and management of sewage treatment fee in Hefei has made some progress, the situation is not optimistic. There are still some problems to be solved in the work of collection and administration.

1) Sewage treatment fees can basically satisfy the normal operation of sewage treatment enterprises, but the incentive policies for improving the management standards have not been established.

Since 1996 the sewage treatment fees came out, although the charge standard of sewage treatment has been improved for three times according to the actual needs, there is still a big funding gap. And the charged sewage treatment fee can not meet the needs of the city's sewage treatment business. For example, from 2006 to 2009, the levied sewage treatment fee is respectively 116 million yuan, 148 million yuan, 185 million yuan, 220 million yuan, which can basically meet the pollution treatment cost at the same period. But the construction and renovation cost of urban sewage treatment facilities is much higher than the actual income of the sewage treatment, costing hundreds of millions of yuan of financial subsidies.

In the future, with the continuous improvement of sewage treatment standards, the cost will be increased [39]. If the government undertake the increased cost, which may increase the financial burden. Therefore, it is necessary to adjust the current fee standards to address the cost of upgrading sewage treatment plant.

2) The sludge harmless disposal cost is not covered in the sewage treatment fee.

The disposal of sludge is mostly used to adopt the way of drying and landfill in Hefei, and the rate of harmless disposal is low. In recent years, part of sludge is burned by Tianyuan thermoelectricity, resulting in increased costs of sludge disposal. At present, the harmless disposal of the sludge is not covered in the sewage treatment fee, which is subsidized by the government [40].

3) It's hard to collect full amount of sewage treatment fees from the users of the well water source.

As the current sewage treatment fee of Hefei, the collection work of sewage treatment fee of the urban public water supply is relatively well. Fees from users of the well water source somewhat increased over the past, but the collecting rate is relatively low, and the emphasis and difficulty in the collection mainly lies in fees from users of the well water source [41].

4) The sewage treatment fee can not be fully used in the sewage treatment project.

Although, the collection and application of sewage treatment fee has made some progress in recent years of

Table 2. The charge standard of sewage treatment fee in Hefei.

\begin{tabular}{|c|c|c|c|c|}
\hline Types of levy & $\begin{array}{l}\text { Water demand in } \\
\text { households }\end{array}$ & $\begin{array}{c}\text { Industrial water } \\
\text { (including official water) }\end{array}$ & $\begin{array}{l}\text { Water demand in business } \\
\text { service }\end{array}$ & Special water \\
\hline $\begin{array}{l}\text { Collection } \\
\text { standard }\end{array}$ & 0.76 yuan $/ \mathrm{m}^{3}$ & 0.845 yuan $/ \mathrm{m}^{3}$ & 1.215 yuan $/ \mathrm{m}^{3}$ & 1.765 yuan $/ \mathrm{m}^{3}$ \\
\hline
\end{tabular}

Note: The municipal water sector is entrusted by the Municipal Finance Department in collecting sewage treatment fee of self owned water, the total income is brought in the same level of finance, realizing "two lines of revenue and expenditure" management. 
Hefei, and the disorder state has gradually changed into relatively standardized, scientific and reasonable state. Relevant laws and regulations such as "Water Pollution Control Law of People's Republic of China" and "Temporary Management Methods of Urban Sewage Treatment Fees in Anhui Province” also clearly stipulates that the collection of sewage treatment fees shall be specially used for the centralized construction, operation and maintenance of urban sewage treatment facilities, which can not be withheld, misappropriated or diverted. However, in actual use of sewage treatment fee, diversion happens sometimes [42].

\subsection{Conclusion}

The state formulates sewage charging policy, and the provincial cities can adjust the charging standards. As a provincial capital city, Hefei has no right to adjust the sewage charging policy, but there still exists a certain possibility while implementing it. The fourth provision of "Management Approach of Levied Standard of Sewage Charges" stipulates as following: according to the local actual situation, the environmental protection administrative departments of municipal (prefecture) level or above can take the method of sampling to measure the sewage volume of catering, entertainment and other small polluters. However, the construction of sewage treatment plant of Hefei is rapid, and almost all enterprises are incorporated into the drainage pipe network. Therefore, there is no need to develop blowdown coefficient for tertiary industry. Generally, raising the standard of sewage charges can not greatly increase the amount of fees. In addition, it is very hard to change the fee into tax, comparing to sewage charges, the reform of enterprises influence larger, and coefficient formulation needs further research. In future, urban sewage treatment plant should be the focus of the monitoring, the supervision of the enterprises and the study on network standards shall be strengthened.

\section{References}

[1] Aregay, F.A., Zhao, M.J. and Bhutta, Z.M. (2013) Irrigation Water Pricing Policy for Water Demand and Environmental Management: A Case Study in the Weihe River Basin. Water Policy, 15, 816-829. http://dx.doi.org/10.2166/wp.2013.005

[2] Balali, L., Khalilian, S., Viaggi, D., Bartolini, F. and Ahmadian, M. (2011) Groundwater Balance and Conservation under Different Water Pricing and Agricultural Policy Scenarios: A Case Study of the Hamadan-Bahar Plain. Ecological Economics, 70, 863-872. http://dx.doi.org/10.1016/j.ecolecon.2010.12.005

[3] Bar-Shira, Z., Finkelshtain, I. and Simhon, A. (2006) Block-Rate versus Uniform Water Pricing in Agriculture: An Empirical Analysis. American Journal of Agricultural Economics, 88, 986-999. http://dx.doi.org/10.1111/j.1467-8276.2006.00911.x

[4] Chica-Olmo, J., Gonzalez-Gomez, F. and Guardiola, J. (2013) Do Neighbouring Municipalities Matter in Water Pricing? Urban Water Journal, 10, 1-9. http://dx.doi.org/10.1080/1573062X.2012.690436

[5] Elnaboulsi, J. (2009) An Incentive Water Pricing Policy for Sustainable Water Use. Environmental \& Resource Economics, 42, 451-469. http://dx.doi.org/10.1007/s10640-008-9218-8

[6] Formiga-Johnsson, R.M., Kumler, L. and Lemos, M.C. (2007) The Politics of Bulk Water Pricing in Brazil: Lessons from the Paraiba do Sul Basin. Water Policy, 9, 87-104. http://dx.doi.org/10.2166/wp.2006.001

[7] Fridman, A. (2015) Water Pricing Reform Analysis: Alternative Scenarios. Journal of Economic Policy Reform, 18, 258-266. http://dx.doi.org/10.1080/17487870.2015.1057510

[8] Garcia-Rubio, M.A., Ruiz-Villaverde, A. and Gonzalez-Gomez, F. (2015) Urban Water Tariffs in Spain: What Needs to Be Done? Water, 7, 1456-1479. http://dx.doi.org/10.3390/w7041456

[9] Garcia, S. and Reynaud, A. (2004) Estimating the Benefits of Efficient Water Pricing in France. Resource and Energy Economics, 26, 1-25. http://dx.doi.org/10.1016/j.reseneeco.2003.05.001

[10] Giannoccaro, G., Prosperi, M. and Zanni, G. (2010) Assessing the Impact of Alternative Water Pricing Schemes on Income Distribution. Journal of Agricultural Economics, 61, 527-544. http://dx.doi.org/10.1111/j.1477-9552.2010.00252.x

[11] Gomez-Limon, J.A. and Riesgo, L. (2004) Irrigation Water Pricing: Differential Impacts on Irrigated Farms. Agricultural Economics, 31, 47-66. http://dx.doi.org/10.1111/j.1574-0862.2004.tb00221.x

[12] Grafton, R.Q., Chu, L. and Kompas, T. (2015) Optimal Water Tariffs and Supply Augmentation for Cost-of-Service Regulated Water Utilities. Utilities Policy, 34, 54-62. http://dx.doi.org/10.1016/j.jup.2015.02.003

[13] Griffin, R.C. (2001) Effective Water Pricing. Journal of the American Water Resources Association, 37, $1335-1347$. http://dx.doi.org/10.1111/j.1752-1688.2001.tb03643.x 
[14] Hajispyrou, S., Koundouri, P. and Pashardes, P. (2002) Household Demand and Welfare: Implications of Water Pricing in Cyprus. Environment and Development Economics, 7, 659-685. http://dx.doi.org/10.1017/S1355770X02000402

[15] Hoffman, J.J. and du Plessis, J.A. (2013) A Model to Assess Water Tariffs as Part of Water Demand Management. Water SA, 39, 423-428. http://dx.doi.org/10.4314/wsa.v39i3.12

[16] Huang, Q.Q., Rozelle, S., Howitt, R., Wang, J.X. and Huang, J.K. (2010) Irrigation Water Demand and Implications for Water Pricing Policy in Rural China. Environment and Development Economics, 15, 293-319. http://dx.doi.org/10.1017/S1355770X10000070

[17] Iglesias, E. and Blanco, M. (2008) New Directions in Water Resources Management: The Role of Water Pricing Policies. Water Resources Research, 44, W06417. http://dx.doi.org/10.1029/2006wr005708

[18] Jiang, Y., Jin, L.S. and Lin, T. (2011) Higher Water Tariffs for Less River Pollution-Evidence from the Min River and Fuzhou City in China. China Economic Review, 22, 183-195. http://dx.doi.org/10.1016/j.chieco.2010.12.006

[19] Latinopoulos, D. (2008) Estimating the Potential Impacts of Irrigation Water Pricing Using Multicriteria Decision Making Modelling. An Application to Northern Greece. Water Resources Management, 22, 1761-1782. http://dx.doi.org/10.1007/s11269-008-9252-x

[20] Madhoo, Y.N. (2004) Political Economy of Water Pricing Policy: Empirical Evidence from Public Utilities in Mauritius. Water Resources Research, 40, W07301. http://dx.doi.org/10.1029/2003WR002903

[21] Mamitimin, Y., Feike, T., Seifert, I. and Doluschitz, R. (2015) Irrigation in the Tarim Basin, China: Farmers’ Response to Changes in Water Pricing Practices. Environmental Earth Sciences, 73, 559-569. http://dx.doi.org/10.1007/s12665-014-3245-2

[22] Manos, B., Bournaris, T., Kamruzzaman, M., Begum, M., Anjuman, A. and Papathanasiou, J. (2006) Regional Impact of Irrigation Water Pricing in Greece under Alternative Scenarios of European Policy: A Multicriteria Analysis. Regional Studies, 40, 1055-1068. http://dx.doi.org/10.1080/00343400600928335

[23] Mao, W.D., Lin, C.T., Ho, C.C. and Wang, C.C. (2008) A Fuzzy Approach to Water Pricing: The Case of Shanghai. Applied Economics Letters, 15, 717-722. http://dx.doi.org/10.1080/13504850600748976

[24] Mesquita, A.M. and Ruiz, R.M. (2013) A Financial Economic Model for Urban Water Pricing in Brazil. Urban Water Journal, 10, 85-96. http://dx.doi.org/10.1080/1573062X.2012.699073

[25] Montginoul, M. (2007) Analysing the Diversity of Water Pricing Structures: The Case of France. Water Resources Management, 21, 861-871. http://dx.doi.org/10.1007/s11269-006-9104-5

[26] Olivier, A. (2010) Water Tariffs and Consumption Drop: An Evaluation of Households' Response to a Water Tariff Increase in Manaus, Brazil. Water Policy, 12, 564-588. http://dx.doi.org/10.2166/wp.2010.045

[27] Renzetti, S., Dupont, D.P. and Chitsinde, T. (2015) An Empirical Examination of the Distributional Impacts of Water Pricing Reforms. Utilities Policy, 34, 63-69. http://dx.doi.org/10.1016/j.jup.2014.12.004

[28] Riegels, N., Pulido-Velazquez, M., Doulgeris, C., Sturm, V., Jensen, R., Moller, F. and Bauer-Gottwein, P. (2013) Systems Analysis Approach to the Design of Efficient Water Pricing Policies under the EU Water Framework Directive. Journal of Water Resources Planning and Management, 139, 574-582. http://dx.doi.org/10.1061/(ASCE)WR.1943-5452.0000284

[29] Rivers, N. and Groves, S. (2013) The Welfare Impact of Self-Supplied Water Pricing in Canada: A Computable General Equilibrium Assessment. Environmental \& Resource Economics, 55, 419-445. http://dx.doi.org/10.1007/s10640-013-9633-3

[30] Romano, G., Masserini, L. and Guerrini, A. (2015) Does Water Utilities’ Ownership Matter in Water Pricing Policy? An Analysis of Endogenous and Environmental Determinants of Water Tariffs in Italy. Water Policy, 17, 918-931. http://dx.doi.org/10.2166/wp.2015.016

[31] Ruijs, A. (2009) Welfare and Distribution Effects of Water Pricing Policies. Environmental \& Resource Economics, 43, 161-182. http://dx.doi.org/10.1007/s10640-008-9228-6

[32] Ruijs, A., Zimmermann, A. and van den Berg, M. (2008) Demand and Distributional Effects of Water Pricing Policies. Ecological Economics, 66, 506-516. http://dx.doi.org/10.1016/j.ecolecon.2007.10.015

[33] Schuck, E.C. and Green, G.P. (2002) Supply-Based Water Pricing in a Conjunctive Use System: Implications for Resource and Energy Use. Resource and Energy Economics, 24, 175-192. http://dx.doi.org/10.1016/S0928-7655(01)00057-4

[34] Shiferaw, B., Reddy, V.R. and Wani, S.P. (2008) Watershed Externalities, Shifting Cropping Patterns and Groundwater Depletion in Indian Semi-Arid Villages: The Effect of Alternative Water Pricing Policies. Ecological Economics, 67, 327-340. http://dx.doi.org/10.1016/j.ecolecon.2008.05.011

[35] Sibly, H. (2006) Efficient Urban Water Pricing. Australian Economic Review, 39, 227-237. http://dx.doi.org/10.1111/j.1467-8462.2006.00415.x 
[36] Speelman, S., Buysse, J., Farolfi, S., Frija, A., D’Haese, M. and D’Haese, L. (2009) Estimating the Impacts of Water Pricing on Smallholder Irrigators in North West Province, South Africa. Agricultural Water Management, 96, 15601566. http://dx.doi.org/10.1016/j.agwat.2009.06.014

[37] Suarez-Varela, M., Martinez-Espineira, R. and Gonzalez-Gomez, F. (2015) An Analysis of the Price Escalation of Non-Linear Water Tariffs for Domestic Uses in Spain. Utilities Policy, 34, 82-93. http://dx.doi.org/10.1016/j.jup.2015.01.005

[38] Tsur, Y., Dinar, A., Doukkali, R.M. and Roe, T. (2004) Irrigation Water Pricing: Policy Implications Based on International Comparison. Environment and Development Economics, 9, 735-755. http://dx.doi.org/10.1017/S1355770X04001494

[39] Veettil, P., Speelman, S. and van Huylenbroeck, G. (2013) Estimating the Impact of Water Pricing on Water Use Efficiency in Semi-Arid Cropping System: An Application of Probabilistically Constrained Nonparametric Efficiency Analysis. Water Resources Management, 27, 55-73. http://dx.doi.org/10.1007/s11269-012-0155-5

[40] Veettil, P.C., Speelman, S., Frija, A., Buysse, J. and van Huylenbroeck, G. (2011) Complementarity between Water Pricing, Water Rights and Local Water Governance: A Bayesian Analysis of Choice Behaviour of Farmers in the Krishna River Basin, India. Ecological Economics, 70, 1756-1766. http://dx.doi.org/10.1016/j.ecolecon.2011.04.018

[41] Wang, H., Xie, J. and Li, H.L. (2010) Water Pricing with Household Surveys: A Study of Acceptability and Willingness to Pay in Chongqing, China. China Economic Review, 21, 136-149. http://dx.doi.org/10.1016/j.chieco.2009.12.001

[42] Willis, E., Pearce, M., Mamerow, L., Jorgensen, B. and Martin, J. (2013) Perceptions of Water Pricing during a Drought: A Case Study from South Australia. Water, 5, 197-223. http://dx.doi.org/10.3390/w5010197 